\title{
Personal counselor quality improvement based on An-Nahdliyah moderation value
}

\author{
Ishlakhatus Sa'idah', Moh. Ziyadul Haq Annajih ${ }^{2}$ \\ ${ }^{1}$ IAIN Madura \\ ${ }^{2}$ STAI Miftahul Ulum Pamekasan \\ najihas@gmail.com
}

Submitted : 2020-03-13, Revised : 2020-05-03, Accepted : 2020-05-22

\begin{abstract}
The counselor's personality is influenced by belief values (belief systems), so these values are essential to consider. Indonesia is a diverse country. Indonesian society is also a religious society. In terms of diversity and terms of religion, there is a match between the two points in the an-Nahdliyah moderation value as the majority group of Indonesian Islam. This study aims to improve the personal quality of the counselor based on an-Nahdliyah moderation values by providing training to prospective counselors. This study uses a onegroup pretest-posttest design. Research subjects were 25 prospective counselors at STAI Miftahul Ulum Pamekasan with simple random sampling. The data analysis technique used a t-test. The results showed that anNahdliyah moderating values training for prospective counselors was effective in improving the personal quality of prospective counselors. This is evidenced by the value of increasing the personal quality of prospective counselors who fall into the medium category. This means that this training is appropriate to be used to improve the personal quality of prospective counselors in providing guidance and counseling services based on the values of tawassuth, tawazun, tasamuh, and i'tidal.
\end{abstract}

Keywords: An-nahdliyah, Counselor's personal, Social

\section{Introduction}

There are three important things related to the quality that must be owned by the counselor, namely knowledge, skills and personality, these three things are a unity that can not be separated. The counselor personality aspect is an important thing that can support success in counseling and guidance activities (Cavanagh, 1982). Corey emphasized that the most important thing in counseling and guidance activities is determined by the personal aspects concerning personal qualities possessed by the counselor (Corey, 2008). The success of counseling and guidance activities depends more on personal quality than the technical mastery of the prospective counselor.

In this case, the most important "tool" to be used by prospective counselors is himself as a person (our self as a person) (Corey, 2008). This is supported by research that shows that aspects of the counselor's personality become a determining factor for the success of counseling and counseling activities, because the counselor must be able to present his identity fully, precisely, and be able to build interpersonal relationships so that it becomes a determinant of the success of counseling services (Putri, 2016). Therefore, the personal qualities of prospective counselors greatly support the success of counseling services in addition to mastery and understanding of counseling techniques (Putri, 2016).

The personal quality of the counselor is very closely related to the values they hold. Values held by counselors are important to consider in counseling and guidance activities, because counseling is loaded with values. As stated by Munandir, namely "Counseling is an understanding and practice that is not merely technical in nature, it is loaded with values" (Munandir, 1989): The values intended here are social, cultural, and religious values (religious values). In line with Munandir's opinion above, Ma'ruf states that the values adopted (belief system) should be considered so that interventions in guidance and counseling activities can take place more relevant and effective (Ma'ruf, 2014). Counselors should be 
able to develop their personal qualities based on their own beliefs (belief system). The counselee's beliefs can affect all aspects of the development and interaction of the counselee's life. If the counselor is able to consider the social values, culture, and attitudes of the counselee towards his belief (religion), then the provision of counseling services by the counselor to the counselee can run more effectively.

So far, the conception of the ideal personal quality of the counselor is dominated by Western theories in which it is loaded with western values ((Wardhani, Farida, \& Yudha, 2019), so that in practice the theory needs to be adapted to the Indonesian context by paying attention social, cultural and religious values. The process of adapting these values often encounters obstacles in practice. In addition to the relatively long internalization process, the application of the values adopted by the counselee should be the main consideration in the activities of guidance and counseling by paying attention to cultural, social, and religious contexts. In practice, Western values that are applied often make the counselor rigid in counseling activities caused by attachment to Western values.

Based on this, it is necessary to pay attention to the Indonesian context which is full of diversity so that the guidance and counseling activities can take place more relevant and effective (Mappiare, 2017). Therefore, it is necessary for the counselor to consider the values adopted as an effort to improve his personal quality, so that guidance and counseling activities can take place more effectively.

Indonesia as a country full of ethnic, ethnic, cultural and religious diversity. Empirically, this diversity can lead to differences, even conflicts between ethnic, ethnic, cultural and religious groups. Therefore, values are needed that can respect the diversity itself. One study of ethnic, ethnic, cultural and religious diversity in Indonesia shows that there are several values that can accommodate this diversity. These values are moderate and tolerant (Prasetawati \& Asnawi, 2018). By paying attention to the diversity and religious side of Indonesia as above, a meeting point appears between the two. This can be seen in the values reflected in the moderating value of an-Nahdliyah as the majority group of Indonesian Islam.

Firqah (group) an-Nahdliyah is a traditional Indonesian Islamic group as well as a majority group with a population of 91.2 million or $36 \%$ of the population of 257 million Indonesians who have the right to vote, even the real population in the field is assumed to be able to exceed the survey figures issued by the Agency Statistics Center (Kompas.com, 2016). In addition, research related to the use of an-Nahdliyah values in viewing diversity and religion in Indonesia has been carried out. One of them, research conducted by (Bukhori, 2018). In his research elaborates on the concept of an-Nahdliyah moderation and religious tolerance. The results of his research show that the concept of an-Nahdliyah moderation is directly proportional to tolerance which illustrates the concept of mutual respect and mutual cooperation between groups of people who have different backgrounds.

Traditionalist Islam which is propped up with an-Nahdliyah group is based on traditions that are depicted in religious practices that are laden with the locality of the archipelago (Mustamir, 2019). Local values are used as a foothold in their religious practices based on al-'adah muhakkamah. An-Nahdliyah group as a traditional Islamic group has a lot of influence on the progress of the Indonesian nation, both in the social, cultural, political, and religious fields (Hakim, 2019). Indonesia as a country full of ethnic, ethnic, cultural and religious diversity. An-Nahdliyah group views diversity as a very valuable potential for the nation so that diversity needs to be managed properly through the existence of values and attitudes that value diversity.

There are several views The an-Nahdliyah group's views developed not only include the doctrine of religious theology alone. However, it is seen as a paradigm (manhaj al-fikr) in thinking and acting that is formulated as a theory and practice that concerns all dimensions of 
life. Manhaj an-Nahdliyah is a method (paradigm) in thinking, behaving and acting on all aspects of life, whether religion, ethnicity, culture and other diversity based on the values of being middle (tawassuth), maintaining balance (tawazun), tolerant (tasamuh), and justice (i'tidal) (Harianto, 2018). These values become the principle of life in the an-Nahdliyah group. In line with research that says the values of an-Nahdliyah can strengthen one another in a religious, social and cultural frame that promotes tolerance in life so that it can create an orderly, harmonious, conducive and peaceful life (Rifa'i, Prajanti, \& Alimi, 2017).

The formulation of an-Nahdliyah moderation values above needs to be internalized in the person of the counselor especially the prospective counselor as an effort to improve personal quality and guidelines for prospective counselors. Internalization of an-Nahdliyah moderation values has previously been carried out in the study as in Annajih's research, namely studies related to the ideal personal characteristics of the counselor in the perspective of Aswaja (Ahlu Sunnah wa al-Jamaah) an-Nahdliyah on the text of the Khittah anNahdliyah. His research has implications for the development of personal qualities of prospective counselors (Annajih, 2018).

The research is a starting point as well as training material in the implementation of this research. Therefore, this study aims to improve the personal quality of prospective counselors based on an-Nahdliyah moderation values through the provision of training to prospective counselors. During this training prospective counselor is expected to be able; (1) understand the values of moderation an-Nahdliyah as manhaj al-fikr; (2) understand the personal qualities of prospective counselors based on an-Nahdliyah moderation values; and (3) able to implement guidance and counseling services in accordance with an-Nahdliyah moderation values.

\section{Methods}

The research design used was pre-experimental (pre-experimental), especially one group with a pretest posttest (one group pretest posttest design). In this study, the anNahdliyah moderation values were trained to 25 prospective counselors at STAI Miftahul Ulum Pamekasan. After the training is carried out a measurement of the personal quality of prospective counselors by giving questionnaires before and after training. Prospective counselors used as samples are selected by simple random sampling technique. 25 prospective counselors were chosen. Data analysis techniques used t-test (paired sample ttest) to see the effect of training in improving the personal quality of prospective counselors. In addition, an N-Gain test was also conducted to see the effectiveness of the training in improving the personal quality of prospective counselors. The data obtained must also meet the prerequisite test that is normally distributed and homogeneous data. The normality test uses the Kolmogorov-Smirnov test, and the homogeneous test uses the Levene test. All tests were performed using SPSS 16 for Windows.

\section{Results and Discussion}

Implementation of an-Nahdliyah moderation value is carried out on 25 prospective counselors at STAI Miftahul Ulum Pamekasan, results before and after the training to improve the personal quality of counselors with an-Nahdliyah moderation value, can be seen in table 1 . 
Table 1. Pretest and Posttest data for prospective counselors

\begin{tabular}{ccccc}
\hline No. & Respondent & Pretest & Posttest & N-Gain \\
\hline 1 & LF & 55.0 & 70.0 & 0.33 \\
\hline 2 & BR & 69.0 & 82.0 & 0.42 \\
\hline 3 & FA & 76.0 & 82.0 & 0.25 \\
\hline 4 & FK & 68.0 & 75.0 & 0.22 \\
\hline 5 & HB & 71.0 & 90.0 & 0.66 \\
\hline 6 & HB & 74.0 & 88.0 & 0.54 \\
\hline 7 & HS & 80.0 & 84.0 & 0.20 \\
\hline 8 & JS & 75.0 & 78.0 & 0.12 \\
\hline 9 & MB & 78.0 & 80.0 & 0.09 \\
\hline 10 & MY & 67.0 & 74.0 & 0.21 \\
\hline 11 & RA & 69.0 & 75.0 & 0.19 \\
\hline 12 & SR & 70.0 & 88.0 & 0.60 \\
\hline 13 & MA & 75.0 & 84.0 & 0.36 \\
\hline 14 & AD & 74.0 & 82.0 & 0.31 \\
\hline 15 & FR & 82.0 & 89.0 & 0.39 \\
\hline 16 & AG & 58.0 & 79.0 & 0.50 \\
\hline 17 & AB & 70.0 & 80.0 & 0.33 \\
\hline 18 & IQ & 82.0 & 96.0 & 0.78 \\
\hline 19 & MH & 75.0 & 88.0 & 0.52 \\
\hline 20 & MM & 67.0 & 76.0 & 0.27 \\
\hline 21 & MI & 69.0 & 74.0 & 0.16 \\
\hline 22 & MH & 70.0 & 77.0 & 0.23 \\
\hline 23 & FM & 75.0 & 78.0 & 0.12 \\
\hline 24 & KS & 63.0 & 81.0 & 0.49 \\
\hline 25 & SB & 77.0 & 82.0 & 0.22 \\
\hline & Total & 71.56 & 81.28 & 0.3404 \\
\hline & & & & \\
\hline & & & \\
\hline & & & \\
\hline
\end{tabular}

Table 1 shows the training of an-Nahdliyah values for prospective counselors can improve the personal quality of the counselor as seen from the pre-test and post-test values. Prospective counselors who have received training will facilitate students for guidance and counseling services. Before prospective counselors provide services, a pretest is conducted using a questionnaire. After the prospective counselor provides services, posttest is given to see the improvement in the personal quality of the counselor. Based on Table 1 it can be seen that there was an increase in response before and after treatment. The response given is assessed as a personal quality counselor.

The pretest and posttest data analyzed had fulfilled the prerequisite test because it was normally distributed and homogeneous so that it could be analyzed using t-test. Based on the results of the t-test shown in Table 1, it can be seen that there are significant differences between the pretest and posttest scores. The posttest value is higher than the pretest value which is $81.28>71.56$. More details can be seen in Figure 1 which shows the magnitude of improvement in the personal quality of the counselor. 


\section{Analysis of Questionnaire Results}

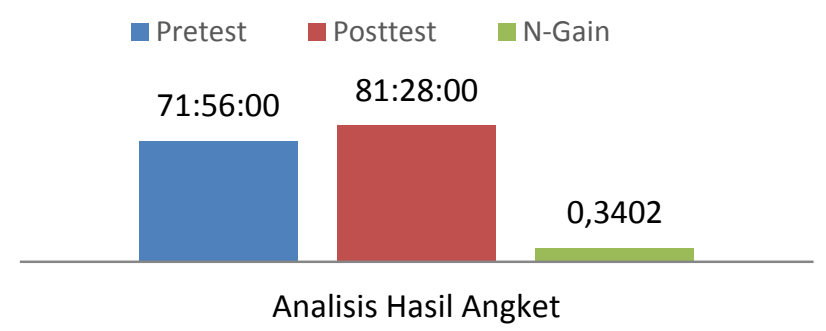

Figure 1. Improving the Personal Quality of Prospective Counselors

The personal quality improvement of prospective counselors analyzed using N-Gain was 0.3404 and included in the medium criteria. This shows that the implementation of anNahdliyah moderating values training for prospective counselors is effective in improving the personal quality of prospective counselors. Of course this result is also reflected in the personal quality of the counselor in accordance with the attitude indicators of the four values of an-Nahdliyah moderation namely the value of tawassuth, tawazun, tasamuh and I don'tidal.

Value tawassuth includes attitudes characteristic including the attitude of the middle of the core harmonizing, compromising, and synthesis, an attitude of open-mindedness, reformative attitude, moderation, an attitude of not easy to blame (judge), and have good knowledge. The attitude of the counselor who is grounded in the value of tawassuth becomes a key instrument that is quite significant in developing an ideal personality for the counselor. This is supported by research that states the value of tawassuth as a middle attitude and is not easy to judge (judge) others, in his research tawassuth value is the key that underlies the success of counseling activities against students (Suryo, Sulistiani, \& Ertanti, 2019). This, as expressed by Carls Rogers, a non-judgmental attitude is one of the key attitudes of unconditional positive regard conditioning (Wilkins, 2000).

Second, tawazun values contain several values and attitudes in them, including proportional attitudes, prioritizing the interests of others, being able to adapt, having integrity, and sincerity to help all of whom have a strong revansi with the characteristics of the counselor as an effort to form an ideal personality for prospective counselors. Tawazun value which is understood as an attitude of balance and harmony that is integrated into one of the characteristics that must be possessed by prospective counselors who determine the success of counseling and guidance activities. This is in line with research that finds genuine, integrated, real, and harmonized counselor abilities that will influence guidance and counseling activities, in his research when the counselor has prepared from these aspects, successful counseling activities (Peace \& Smith-Adcock, 2018).

Third, the value of tasamuh in it contains several values and attitudes, including the attitude of respect and love, the attitude of mutual cooperation, open thinking, maintaining brotherhood and unity, and the attitude of togetherness. In this study the value of tasamuh is very emphasized, namely the attitude of tolerance, respect, and respect for others, and that is able to form an effective counselor. Tasamuh values are in line with Rogers' concept and theory, namely unconditional positive regard, which means the attitude of the counselor who accepts the counselee fully, the attitude of the counselor who values the counselee unconditionally, and the attitude of the counselor who respects the counselee completely regardless of the counselee's background, whether racial, ethnic, cultural, and religion. In line with research that found unconditional positive regard can be a path to psychological wellbeing, not only applied by counselors, clients are also guided to be able to appreciate 
themselves with all their weaknesses and strengths ((Murphy, Joseph, Demetriou, \& KarimiMofrad, 2017).

Fourth, the value does not contained in it contains several values and attitudes, including the attitude of being fair, upholding equality, and honesty, all of which demand to be fair in looking at all matters of life. Iidal value is understood as an upright attitude that upholds justice, honesty, and equality. This attitude is manifested in his attitude which always upholds the values and norms in force. In the activities of guidance and counseling has implications for the attitude of counselors who uphold justice without differentiating the counselee's background, both race, ethnicity, culture, and religion. The statement is supported by research that says it is very important to be aware of human diversity, especially for counselors who have an important role in shaping the character of fairness and tolerance to students, in his research fairness and cultural tolerance, religion taught to students makes minorities feel happy (Ahmad \& Amin, 2018).

Fairness is regulated in a formulation of the counselor's code of conduct which requires that the counselor be fair to the counselee. This is as regulated in the counselor's code of ethics relating to the attitude of justice. Justice means providing services to all counselees, regardless of gender, age or disability. All of these should have the same rights in the implementation of guidance and counseling activities (Luke, Gilbride, \& Goodrich, 2017). This research has a contribution to prospective counselors, prospective counselors can understand the values of an-Nahdliyah moderation as manhaj al-fikr, able to internalize the values of an-Nahdliyah moderation, and be able to apply guidance and counseling services based on the attitude indicators of the four values an-Nahdliyah moderation namely the value of tawassuth, tawazun, tasamuh and I'tidal

\section{Conclusions and Suggestions}

Based on the results of the study showed that an-Nahdliyah moderating values training for prospective counselors was effective in improving the personal quality of prospective counselors. This is evidenced from the value of increasing the personal quality of prospective counselors who fall into the medium category. This means that this training is appropriate to be used to improve the personal quality of prospective counselors in providing guidance and counseling services.

The implication of this research is expected to be able to contribute to the field of guidance and counseling as scientific information relating to the formation of the ideal personal characteristics of the counselor that is appropriate or based on the values of Aswaja an-Nahdliyah. Specifically, this research is expected to be able to contribute to guidance and counseling practitioners, especially for counselors from the Aswaja an-Nahdliyah Islamic group as an effort to develop counselor personality competencies that are compatible with Aswaja an-Nahdliyah. In addition, training to improve the personal quality of prospective counselors can be used as an alternative to improving the competency of prospective counselors.

\section{References}

Ahmad, K. I., \& Amin, B. (2018). The role of cross-cultural counselling in efforts to improve the tolerance of Tionghoa ethnic students. 1st International Conference on Creativity, Innovation and Technology in Education (IC-CITE 2018). Atlantis Press.

Bukhori, I. (2018). Nilai-nilai pendidikan multikultural dalam mata pelajaran Aswaja dan keNU-an siswa SMP/MTs. At-Ta 'lim: Jurnal Pendidikan, 4(1), 35-56.

Cavanagh, M. (1982). The Counseling Experience: A theoretical approach. California: Brooks/Cole Publishing Company. 
Corey, G. (2008). Theory and practice and psychotherapy of counseling. Animal Genetics.

Hakim, D. (2019). Inclusivism and exclusivism as well as their effect on islamic education based multicultural. International Journal of Islamic Education, Research and Multiculturalism (IJIERM), 1(2), 18-29.

Harianto, B. (2018). Relasi teologi Aswaja dengan HAM perspektif Kiai Said Aqil Siroj. Humanistika : Jurnal Keislaman, 4(2), 23-38.

Kompas.com. (2016). Buktikan klaim sebagai ormas terbesar, NU terbitkan kartu anggota nasional artikel ini telah tayang di Kompas.com dengan judul "buktikan klaim sebagai ormas terbesar, NU terbitkan kartu anggota nasional", https://regional.kompas.com/read/2016/04/07/140136.

Luke, M., Gilbride, D., \& Goodrich, K. M. (2017). School counselors' approach to ethical decision making. Journal of Counselor Leadership and Advocacy, 4(1), 1-15.

Ma'ruf. (2014). Landasan bimbingan dan konseling (perspektif islam dan filsafat eksistensial humanistik; sebuah komparasi). Yogyakarta: Aswaja Pressindo.

Mappiare, A. (2017). Meramu model konseling berbasis budaya nusantara: Kipas (konseling intensif progresif adaptif struktur). Naskah Pidato Pengukuhan Guru Besar Universitas Negeri Malang.

Moh. Ziyadul Annajih. (2018). Karakteristik pribadi ideal konselor dalam perspektif Aswaja an-Nahdliyah (Kajian hermeneutika teks khittah an-Nahdliyah). Pascasarjana UM.

Munandir. (1989). Bimbingan sekolah di Indonesia: Corak yang bagaimana?. Naskah Pidato Pengukuhan Guru Besar IKIP Malang.

Murphy, D., Joseph, S., Demetriou, E., \& Karimi-Mofrad, P. (2017). Unconditional positive self-regard, intrinsic aspirations, and authenticity: Pathways to psychological well-being. Journal of Humanistic Psychology.

Mustamir, A. K. (2019). Islam nusantara: Strategi perjuangan "keumatan" Nahdlatul Ulama. Jurnal Intelektual: Jurnal Pendidikan Dan Studi Keislaman, 9(3), 297-310.

Peace, P., Smith, Adcock, S. (2018). A conceptual framework for felt sense awareness in counselor preparation. The Journal of Humanistic Counseling, 57(3), 208-222.

Prasetawati, E., \& Asnawi, H. S. (2018). Wawasan islam nusantara: Pribumisasi nilai-nilai kearifan lokal di Indonesia. FIKRI: Jurnal Kajian Agama, Sosial Dan Budaya, 3(1), 219-258.

Putri, A. (2016). Pentingnya kualitas pribadi konselor dalam konseling untuk membangun hubungan antar konselor dan konseli. Jurnal Bimbingan Konseling Indonesia, 1, 10-13.

Rifa'i, A., Prajanti, S. D. W., \& Alimi, M. Y. (2017). Pembentukan karakter nasionalisme melalui pembelajaran pendidikan Aswaja pada siswa Madrasah Aliyah Al Asror Semarang. Journal of Educational Social Studies, 6(1), 7-19.

Suryo, M. H., Sulistiani, I. R., \& Ertanti, D. W. (2019). Implementasi nilai-nilai Aswaja dalam mengembangkan akhlak siswa kelas VII MTS Wahid Hasyim 01 Dau Kabupaten Malang. Vicratina: Jurnal Pendidikan Islam, 4(5), 159-163.

Wardhani, N. S., Farida, E., \& Yudha, E. S. (2019). Profil kompetensi pedagogik dan profesional guru bimbingan dan konseling SMA di Kota Bandung. Indonesian Journal of Educational Counseling, 3(2), 147-154.

Wilkins, P. (2000). Unconditional positive regard reconsidered. British Journal of 
Counseling, 28, 143-155. 